

\title{
VIEWPOINT
}

\section{How Optional Should Regional Anatomy Be in a Medical Course? An Opinion Piece}

\author{
BERNARD J. MOXHAM ${ }^{1,2} *$ AND DIOGO PAIS 3 \\ ${ }^{1}$ Cardiff School of Biosciences, Cardiff University, Museum Avenue, Cardiff, CF10 3AX, Wales, United Kingdom \\ ${ }^{2}$ Department of Anatomical Sciences, School of Medicine, St George's University, Grenada, West Indies \\ ${ }^{3}$ NOVA Medical School, NOVA University of Lisbon, Campo dos Martires da Patria 130, Lisboa,
} 1169-056, Portugal

\begin{abstract}
The use of optional (elective) courses within the medical curriculum is increasingly being seen as a way of allowing students to pursue their studies according to their personal interests. For anatomy, particularly where the subject is being taught in an integrative curriculum and by means of a systemic approach, the development of elective regional anatomy courses is being employed to reintroduce regional anatomy and/or dissection by students. However, there is presently little evidence that objectively evaluates optional/elective courses. In this paper we critique the concept and practice of using elective courses and assess whether their deployment is ultimately in the interests of medical education, the medical profession, society in general and the layperson (potential patient) in particular. Clin. Anat. 00:000-000, 2016. ๑2016 Wiley Periodicals, Inc.
\end{abstract}

\section{Key words: medical education; anatomy; core syllabus; option/elective medi- cal courses}

\begin{abstract}
The place of gross anatomy in the medical curriculum remains a topic of considerable debate, and occasional controversy, in terms of the time allocated, timing within the course, content and clinical relevance, and the use of cadavers and dissection by students. Indeed, major doubts remain as to the best way to teach this basic science, particularly at the undergraduate level (e.g., Plaisant et al., 2004; Wong and Tay, 2005; Smith, 2005; McLachlan and Patten, 2006; Bay and Ling, 2007; Collins, 2008; Fitzgerald et al., 2008; Jamshidi et al., 2008; Xu, 2008; Memon, 2009; Mitchell and Batty, 2009; Mukhtar et al., 2009; Ahmed et al., 2011; Banerjee and Bancil, 2011; Braun, 2014; Pais and Moxham, 2013). These concerns are not confined to recent history (e.g., Lockwood, 1888; Dwight, 1896; Walsh, 1904; Berry, 1921; Hamilton, 1947; Khan, 1947; Von Bonin, 1947; McMurray, 1949; Ampil, 1949; Anson, 1956, 1961; Dewhurst, 1958; Friel, 1963). It is during the past few decades, however, that there has been great pressure to change medical curricula (Moxham and Moxham, 2007; Moxham and Plaisant, 2007; Patel and Moxham, 2008; Kerby et al., 2011; Moxham et al., 2011; Pais and Moxham, 2013) and this has resulted in a profound change in the way anatomy is taught in
\end{abstract}

medical schools around the world (Coupland et al., 1976; Esperanca-Pina, 1976a,b; Esperanca-Pina et al., 1980; Jones, 1997; Pais, 1997; Dinsmore et al., 1999; Cahill et al., 2000; Bay and Ling, 2007; Collins, 2008; Fitzgerald et al., 2008; Jamshidi et al., 2008; Patel and Moxham, 2008; Banerjee and Bancil, 2011; Kerby et al., 2011; Buckenham, 2013; Pais and Moxham, 2013). To take as an example just the USA, Drake et al. (2014) have reported that, compared with earlier findings (Drake et al., 2002, 2009), there has been a significant drop in the average number of hours devoted to gross anatomy in American medical schools (from $\sim 170 \mathrm{~h}$ in 2002 to $147 \mathrm{~h}$ in 2014).

A particular concern has been the drive to decrease time spent on teaching anatomy (de Barros et al., 2001; Fitzpatrick et al., 2001; Morley, 2003; Older, 2004; Gunderman and Wilson, 2005; Ramsey, 2005;

\footnotetext{
*Correspondence to: Bernard J. Moxham, Cardiff School of Biosciences, Cardiff University, Museum Avenue, Cardiff CF10 3AX, Wales, United Kingdom. E-mail:
}

Received 6 June 2016; Accepted 12 June 2016

Published online in Wiley Online Library (wileyonlinelibrary.com). DOI: $10.1002 / \mathrm{ca} .22742$ 
Abdul-Ghani, 2006; Chew et al., 2006; Linton, 2006; Purkayastha et al., 2007; Dettmer et al., 2010; Jack and Burbridge, 2012; Nutt et al., 2012; Drake et al., 2014). One of the most cited factors underpinning the decrease in time allocated to anatomy has been the erroneous notion that the subject is based mainly on factual memorization and not directed to clinical skills (Moxham and Moxham, 2007; Patel and Moxham, 2008; Kerby et al., 2011; Moxham et al., 2011; Pais and Moxham, 2013). Currently, since critical thinking and student independent learning is privileged within the medical curriculum, the importance of gross anatomy has often been downgraded in many medical schools (General Medical Council, 1993; Murphy and Handa, 2004; Older, 2004; Rulli, 2004; Moxham and Moxham, 2007; Moxham and Plaisant, 2007; Patel and Moxham, 2008; General Medical Council, 2009; Kerby et al., 2011; Moxham et al., 2011; Pais and Moxham, 2013). Although the consequences of the decline in gross anatomy have been denounced by many clinicians, especially surgeons and radiologists (Forrester, 1971; Mottershead, 1980; de Barros et al., 2001; Fitzpatrick et al., 2001; Older, 2004; Gunderman and Wilson, 2005; Ramsey, 2005; Abdul-Ghani, 2006; Linton, 2006; Purkayastha et al., 2007; Seyfer et al., 2007; Dettmer et al., 2010; Moxham et al., 2011), this appears to have had little effect on those politico-educational authorities (e.g., deans and medical educationalists) who are responsible for developing and overseeing medical curricula. This is occurring despite the fact that, for many stakeholders in medicine, attitudes concerning the importance of the anatomical sciences toward clinical practice is recognized. Indeed, such positive attitudes are shown by medical students (Moxham and Moxham, 2007; Kerby et al., 2011; Moxham et al., 2016) and laypersons (Moxham et al., in press), as well as by professional anatomists whether "traditionalist" or "modernist" (Patel and Moxham, 2006).

Changes to the teaching of anatomy involve not only reduction in the time allocated to the discipline but also the introduction of new teaching methods, particularly since there has been a decline in the numbers of professional anatomists (Pinto-Machado, 1991, 1992; Rosado-Pinto, 1993; Rosado-Pinto and Bensabat-Rendas, 1994; Pereira and Rosado-Pinto, 1995; Pinto-Machado,1995, 1996; Pais, 1997; Plaisant et al., 2001; Plaisant et al., 2004; Moxham and Plaisant, 2007; Collett et al., 2009; Moxham et al., 2011; Pais and Moxham, 2013). In some medical schools, there has been a push to eliminate some of the traditional methods, such as cadaveric dissection, invoking either the scarcity of donors or claiming that dissection is obsolescent and perhaps even atavistic in the current technological era (Bhadkamkar and Bhatt, 1959; Amataguirre, 1963; Schweisthal and White, 1970; Hamel, 1975; Pais, 1997; Johnson, 2002; McLachlan et al., 2004; Plaisant et al., 2004; Stansby, 2004; Rizzolo and Stewart, 2006; Seyfer et al., 2007; Barberini and Brunone, 2008; Korf et al., 2008; Hill and Shalhoub, 2011; Naz et al., 2011; Burgess et al., 2012; Pais and Moxham, 2013). While there are many detractors to such developments, given the unparalleled experience provided by human cadaveric dissection (Anson and Davenport, 1954; Bird, 1979; Andrea et al., 1996; Mitchell et al., 2004; Krych et al., 2005; Regan de Bere and Petersen, 2006; Patel and Moxham, 2006), Drake et al. (2014) have reported that many anatomy courses in the USA are now part of integrated curricula.

The reasons for there being controversy regarding the role of anatomy in the medical curriculum, and also for there being so extensive a literature on anatomical education, are rooted not only in ideological arguments between "modernist" and "traditionalist" factions but mainly in our view because of the absence of quantitative, and rigorous, pedagogic research into the merits of different methods for teaching and learning anatomy (Pais, 1997; Pais and Moxham, 2013).

Even within the anatomical community, there is relatively little discussion about whether gross anatomy should be taught systemically and/or regionally or whether anatomy should be integrated or remain as a stand-alone course. A systemic approach classically considers organs and tissues into the broad categories of the musculoskeletal system (including osteology, arthrology, and myology), angiology (the cardiovascular system), neurology, and splanchnology (digestive, respiratory, endocrine, and urogenital systems). The regional approach describes the existing structures in the major regions (head and neck, thorax, abdomen, pelvis and perineum, back and limbs) and subdivisions of these regions (e.g., infratemporal fossa, pleural cavity, epigastric region, cubital fossa) (Pais, 1997; Pais and Moxham, 2013). In a previous article (Pais and Moxham, 2013) we discussed the advantages and disadvantages of adopting systemic or regional approaches to teaching gross anatomy. We concluded that the systemic approach has the advantage of enabling appreciation of the entirety of organs constituting major systems pathologies while providing a framework for the understanding of the biomedical sciences. Thus, this approach fits most comfortably with integrated medical curricula. On the other hand, the regional approach fits better with the requirements for the training of surgeons or radiologists, and it permits an understanding of how trauma/lesions at specific locations affect the related tissues at those locations. It is clear that it is difficult for those who are taught gross anatomy only by a systemic approach to then be able to apply their knowledge to an understanding of regional anatomy. Furthermore, the systemic approach is not best suited for teaching that involves dissection. Overall, we suggested that, even within health care studies courses such as medicine that are integrated, there should be a standalone component for the study of gross anatomy that takes a regional approach. Given the limitations of time and resources, the attraction of using optionality through elective courses to teach regional anatomy is obvious.

We will now consider the use of optionality/elective courses in medical curricula in various parts of the world and assess the use of such courses. Following this critique, we will return to the case of regional anatomy and provide conclusions and some recommendations. 
It has become fashionable to include elements of optionality within the medical curriculum. The implication is that students have a choice of courses beyond what is considered to be 'core'. Agarwal et al. (2015) have recently provided a systematic evaluation of 'preclinical' elective courses in the medical curriculum and have reported that "the range of electives available and their impact upon medical student education are not well described in the literature." It is recognized that the prime purpose of such courses is to introduce flexibility in the medical course and to allow the students to following their own individual pathways by pursuing their own personal interests. In addition, Agarwal et al. (2015) stated that electives "teach medical students useful skills, increase student wellness" (although no evidence was provided to support this) and "impact eventual career choices" (again no evidence was made available for this assertion). Of course, anatomists have developed gross anatomy electives (sometimes with dissection) for 'political' reasons in order to counter the loss of gross anatomy or practical training within the "core" courses. Agarwal et al. (2015) identified electives mainly in clinical skills, the humanities (e.g., history of medicine, literature in medicine), student lifestyle, leadership, ethics, health policy, business, foreign languages, and speciality-specific electives that would include the teaching of regional anatomy. They also reported that electives used a variety of teaching methodologies, although lectures were still frequently employed, and found that there was considerable variation in the type and quality of assessment methods. They asserted that "successful courses maximize the use of elective time without requiring extensive amounts of outside work for the class, in deference to students' workloads."

From our own survey of information about optional/elective courses available on the internet, we agree with Agarwal et al. (2015) that there is a paucity of available information that is useful to evaluate pedagogic efficacy. We have particularly observed that many, if not most, medical schools in the USA have embraced the concept. Nevertheless, certified data related to these types of programmes do not presently exist. For the anatomy electives in the US, they are often called "Surgical Anatomy" or "Clinical Anatomy" electives and they are most frequently offered in the 3 rd and/or 4th years of medical school. They are usually 2 or 4 weeks long and can take many forms. For example, a student may be paired with a surgeon or surgical group and assist in the operating room, students may also undertake additional work in the anatomy laboratory. The electives may also involve some type of research activity or working with residents or involve the teaching of anatomy to medical students (peer teaching). Across the globe, we found that an increasing number of schools are choosing to include some type of elective courses within the medical curriculum. Furthermore, there is a great diversity of programmes where anatomical 'Elective Curricular Units (ECU)' or 'Elective Courses (EC)' or 'Student Selected Components (SSC)' appear. There are schools that do not use electives and schools that use compulsorily electives where the results do not contribute toward the final score while others employ electives that do count toward the final student score. There are schools where the medical curriculum is grounded in multiple electives, schools that include them during the early years of the medical course and others that only employ them at the end of the course. Some schools schedule electives within the academic calendars and timetables whereas others only allow electives to be pursued out of the academic hours (or even during vacation time). There is also considerable variation regarding the assessment of student performance and whether they achieved the learning objectives of the electives. Attendance, observation of skills, attitudes and behaviour, oral (viva voce) examinations, oral presentations, written examinations (with either closed or open questions), essay writing, discussion with faculty are all mentioned. While it might be argued that such diversity is to be expected (and even encouraged by some educationalists who argue in favor of students having a variety of learning styles), the degree of diversity does not seem to us to be commensurate with the attainment of recognized standards or even to accord with the educational principles of maintaining consistency, reliability, and even transparency. Of particular concern for us was the discovery that some anatomical optional/elective courses have titles that include words such as "fundamental" or "basic" (words that are appropriate for core material that should not be the subject of electives!).

Should the reader desire to consult some of the curricula that include anatomical elective courses and to guage the variety of approaches we suggest visiting initially the websites for the following medical schools: Indiana University (Bloomington, IN), Ottawa University (Canada), Jinan University (PR of China), Harvard Medical School (Boston, MA), Kosice University (Slovenia), Case Western Reserve University (Cleveland, $\mathrm{OH})$, MacGill University (Montreal, Canada), Mayo Clinic (Rochester, MN), Cardiff University (UK), Stanford University (USA), NOVA Medical School (Lisbon, Portugal), UCLA (Los Angeles, CA), Sidney University (Australia), University of Sarjah (United Arab Emirates), Aberdeen University (UK).

It might be summarized that the introduction of optionality into a medical course is based upon tried and tested education principles. However, as indicated by Agarwal et al. (2015), little information is available as yet in the literature. Here, we will assess the concept of optionality by addressing eight fundamental questions:

Question 1-How does a medical school define 'core' and how is the choice of elective courses arrived at?

In a review of the development of 'core' syllabuses in the anatomical sciences, Moxham et al. (2014) indicated that, to date, there have been several commendable attempts to define core syllabuses in gross anatomy (Leonard et al., 1996, 2000; Griffioen et al. 1999; Leonard et al., 2000; Kilroy and Driscoll, 2006; McHanwell et al., 2007; Swamy et al., 2014; Tubbs et al., 2014; Smith et al., 2016). However, other, more specialized, anatomical sciences have been relatively poorly served by the development of core syllabuses, although the International Federation of 
Associations of Anatomists is in the process of devising such syllabuses (Moxham et al., 2014) by means of Delphi Panels [e.g., see Moxham et al. (2015) for a neuroanatomy syllabus].

There is much scepticism regarding the ways in which core syllabuses are formulated, as well as concern about their effectiveness politically. However, it should be recorded that the existing core syllabuses have met with some success. For example, in the case of the syllabus devised by the UK and Irelandbased Anatomical Society, when the General Medical Council published its educational directions in Tomorrow's Doctors (2009), the Council singled out the core syllabus as a document that medical schools should be made aware of. Even so, how many medical schools took action according to their core syllabus is not known. Criticisms that have been leveled at the available core syllabuses include:

- It is not usual for such syllabuses to be 'democratically' developed. Usually, a selected 'committee of experts' is assembled and their deliberations are published (often without, consultation with another groups). The findings that emerge from this approach usually lack a dynamic structure and are often handed down to the community as written in 'tablets of stone.'

- Although some anatomists are clinically qualified many are not and therefore care should be taken to seek clinical input. Furthermore, care should also be exercised to ensure that vested interests do not greatly sway the outcomes.

- Most core syllabuses lack a worldwide perspective, being devised locally/nationally.

- Not all stakeholders (anatomists, clinicians, deans, medical educationalists, and students) have access to the proposed core syllabus to be able to comment and amend the proposals. Thus, it is our view that a core syllabus should be a perpetually evolving entity, giving dynamism and 'fluidity' to the process that allows debate.

Whatever methods are used to devise core syllabuses, it is clear that, until core material is defined in the medical curriculum and generally agreed across the Higher Educational sector, optionality has conceptually no real foundations since each institution or medical school will have its own notions of 'core' that will be poorly constituted according to clear educational principles and the needs of medical practice. Furthermore, from our review of what is written about optional or elective courses in the literature, the diversity of approaches and the poverty of explanations concerning the underpinning principles merely adds to the criticisms.

Finally, already medical education is fractured worldwide by diversity such that there is difficulty in appreciating the standards set (and thus the quality of future medical practitioners). The introduction of electives further complicates diversity between students within a cohort such that the very different educational experiences might lead to an unacceptable deficiency regarding consistency, reliability, and transparency.
Question 2-How do the admission procedures for optional/elective courses affect choice and who exactly is the consumer?

It seems that very often there are limits or fixed numbers of students on an elective course and therefore not all within a student cohort are free to attend. This in itself undermines the concept underpinning electives that holds that students can follow their own individual pathways by pursuing their own personal interests. Given fixed numbers on an elective, special admission criteria are frequently employed. In some instances, the students who are more able academically gain admission and this can occur in preference to those who have greater motivation or potential for benefitting from the elective. Furthermore, admission is sometimes on a 'first come first served' basis. Our concern here is that practical considerations, understandable as they might be for course organization, nevertheless might undermine an important educational principle. Indeed, it can be argued that students should be 'profiled' to advise them about their suitability to join specific electives.

In terms of who is the beneficiary (or consumer) of optional/elective courses, the common sense response is that it is beneficial to the students who are following their own personal interests. However, the assumption here is that the medical course can be organized with the degree of flexibility found in degree courses for the arts and sciences. For example, a student who prefers to read Jane Austin rather than James Joyce for an English literature degree is no better or worse than another student who makes a different choice. Consider also that a student in the biological science can choose without prejudice between a module in ecology or evolutionary biology. However, this type of flexibility is a fallacy in medicine where there is a responsibility to society that means that careless flexibility can lead to inconsistency and lack of reliability and transparency that cannot in the long term be countenanced. Furthermore, elective courses in medicine are based upon the misconception that the student is the ultimate consumer of an education overseen and controlled by the 'politicoeducational authorities' at the medical school who devise the curriculum. However, in our increasingly consumerist societies, it is the medical profession, the politicians and civil servants governing society and, above all, the layperson (patient and potential patient) who are the consumers and who should expect appropriate standards and consistency, reliability, and transparency. Recently Moxham et al., in press, have reported that laypersons in the UK and in France strongly held the view that cutting the amount of anatomy taught at medical school and not undertaking cadaveric dissection severely affects the esteem of the medical profession in their eyes. This is a serious point and the medical profession ignores this sentiment at its peril. To pursue this political matter a little further, there is a paradoxical mismatch between the public desiring increasing resources being found for health care and the demands of financial austerity. Indeed, politicians do worry about the training of health care professionals and the commensurate costs. Should they deem the degree of flexibility 
within the medical curriculum to be undesirable (perhaps even a 'luxury'), perhaps adding to the costs incurred and the time it takes for medical practitioners to be competent to practise, then the medical profession could suffer adverse political effects.

Question 3-How do students make their choices?

Assuming that students can freely be admitted to an elective course, one would like to believe that a student would make choices according to their interests, abilities, and/or career aspirations. However, these matters are rarely considered when advising students about their choices (i.e., assuming that advice is offered). Furthermore, on talking confidentially with students, other matters such as the personalities of the teachers, whether the subject is deemed easy or hard, the time taken to complete the course and tasks set, whether there are examinations or just "satisfactory completion" of the course, or even how hard are the examinations, feature strongly in the choices made. For electives in regional anatomy it has even been suggested that students do not chose the perineum because of perceived difficulty of the topic and/or dissection but also because of embarrassment. These reasons, understandable as they are from the student perspective, are not in themselves satisfactory and point to the fact that there is too much diversity and too little consistency in electives and also a lack of reliability and transparency.

Question 4-How well-received are optional/elective courses by the students?

Elective courses not surprisingly are often assessed by students filling out questionnaires at the end of the courses. These assessments usually mostly evaluate 'student satisfaction' and 'teacher competence.' Such assessments are however inadequate since, in the long term, whether or not the students made correct choices according to information obtained, skills learned or career aspirations satisfied are not evaluated. Therefore, electives in the early parts of the medical course may be inconsequential in terms of the real needs of the students' training regarding the development of their competencies once they have chosen their career pathway.

Question 5-What is the underlying principle that might suggest that students who are taking certain options are more fitted (and have a better career pathway) for specific medical/surgical specialities?

To date, this question cannot be adequately answered since studies have not been undertaken to show whether taking specific electives naturally leads to the students eventually taking a related career pathway. Indeed, we need to know whether, for example, students who take an elective in gross anatomy are more or less likely to pursue a career in surgery. This is of importance for the very concept of taking electives since, if it is found that students for an anatomy elective are just as likely to pursue a career where anatomy is not a basic element, then there is a failure of educational principle to be addressed.

Question 6-What is the educational value added?

It can be summarized that a variety of generic skills can be attained from the following educational methodologies that seem to be particularly appropriate to elective courses (especially if there are small numbers of students):

\author{
Mastery learning \\ Peer tutoring \\ Student control over learning \\ Individualized instruction \\ Problem-solving learning \\ Problem-solving teaching
}

All of these methodologies have been assessed by a synthesis of many studies and meta-analyses by the educationalist Hattie (2009). He reported that 'Mastery Learning' is where the student learns by being provided with "clear explanations of what it means to 'master' the material being taught" and is given numerous feedback opportunities. This teaching approach was assessed by Hattie who analyzed 377 studies involving 9,323 students. He reported that the evidence was in favour of this methodology having significant 'desired effects' and consequently this approach, with small groups of students, may have educational value within the context of optional/elective courses which go beyond 'core' material. This was also found to be the case for 'Peer Tutoring' where Hattie analyzed 63 studies and 2 meta-analyses. As the name implies, peer tutoring involves recruitment of the students as coteachers. Scott et al. (2014) have written about this aspect of learning specifically for anatomy where there is collaborative learning through the use of 'Shadow Modules.' The 'Peer Tutoring' approach readily leads on to 'Student control over learning' where there is much pedagogic choices are available because it is believed that students have a variety of learning styles. However, Hattie analyzed 65 studies and 2 meta-analyses to show that, while there is a significant effect on student motivation, the effects on student learning itself is not of greater value than normal 'developmental effects.' This seems also to be the situation for approaches utilising 'Individual Instruction' where "each student has unique interests and past learning experiences" that requires 'an individualized instructional program... allowing for flexibility in teaching methods.' Hattie analyzed 600 studies involving 9,380 students and concluded that the evidence was that there were no 'desired effects' for this approach per se and only 'teacher effects.' This being the case, the evidence is not advantageous to the notion essential to elective courses that they introduce flexibility in the medical course and allow the students to follow their own individual pathways by pursuing their own personal interests. Much is made these days of the use of 'Problem-based Learning' in the medical course and it might be considered that the smaller numbers of students within optional/ elective courses might benefit from this pedagogic approach. Hattie analyzed 285 studies for this methodology that involved 38,090 students and reported that were no 'desired effects.' However, when analysing 221 studies with 15,235 students for 'Peer-based Teaching,' there is a significant 'desired effect.' This suggests that the use of scenarios can be successful where the problems are identified and prioritized by teacher instruction and where students are provided 
with the various solutions. Overall, therefore, the educational evidence is mixed for there being educational value added that is specific for optional/elective courses.

Question 7-How are the students on optional/elective courses examined and what are the consequences of the students' performance?

We have already commented on the variety of assessment strategies that have, or can be, employed with optional/elective courses, from 'satisfactory completion,' through formative and continuous assessments, to end-of-course summative examinations. We have also reported that one of the reasons for students choosing a particular elective might be the types of assessments to be undertaken or the perception of the degree of difficulty of the assessments. Here, comment needs to be made about outcomes should a student fail to meet the course requirements. One can ask the question in conceptual terms that, if a medical course has subdivided its curriculum into core material and optional material, then what is the principle underlying the requirement to pass an elective course? Should the core be correctly defined (a BIG if!) then the core material would be what is required to become a member of the medical profession and to go on to further training for the practise of medicine. The optional/elective courses are 'add-ons' which, if not used to direct students to specific career pathways, are there just to add 'interest,' generic and nongeneric skills, and/or intellectual and cultural value to the students' education. Can it be appropriate, therefore, in these circumstances to make passing the elective course mandatory so that the student can go on further study in the medical course? In other words, have the medical authorities really grasped the differences between the teaching, assessment and purposes of core and noncore courses? To provide the student at the end of the medical course with a transcript that shows her/his performances in both core and elective courses and that can be of benefit for future employers.

Question 8-How might optionality eventually drive major changes in medical education?

Although we do not pretend that we have clear sight into the future, we can envisage what might be the logical consequences of different universities or medical schools following different core and elective courses. Putting aside the issues relating to following the important educational principles of maintaining CONSISTENCY, RELIABILITY, and TRANSPARENCY within and between courses, it is not unreasonable to predict that these principles will be forced upon the medical curriculum either by very stringent, rigorous, and independent oversight of the courses and/or by the need for students to pass examinations organized on a state-wide (national) basis and not just by the university's own examinations alone (as happens still in many parts of the world). A further possible consequence relates to whether all universities should teach, or need to teach, ALL aspects of medicine. Given the high costs of training competent medical practitioners, it is possible that different universities/ medical schools will 'evolve' to specialise in different aspects of medicine through the optional courses. For example, University A might have core and elective courses that direct the students toward surgery. University $B$, on the other hand, might have core and elective courses more suited to internal medicine or to the more social aspects of medicine. University $\mathrm{C}$ on the other hand might have courses more appropriate for General Medical Practice. Those against such developments would argue that students require time to decide on their career pathways. Indeed, if so, why organise electives early in the medical course and why do we require students who wish to be dental surgeons to decide on their careers before they come to university? Our prognostications undoubtedly will be very unpalatable to many involved in medical training but 'logic is logic' and economics is about 'saving money' so it is wise to understand that educational methodologies have consequences beyond merely imparting knowledge, skills, and attitudes to the students!

Returning to the use of optional/elective courses for anatomy, we would argue that the educational case has not been adequately made for their widespread use; even though it is understandable that politically, where anatomy has been cut within a medical school, this is a way of salvaging some of the material within the medical curriculum. It is not just our opinion but in accordance with the opinions of medical students, professional anatomists (whether 'modernist' or 'traditionalist'), and laypersons (Patel and Moxham, 2006, 2008; Moxham and Moxham, 2007; Patel and Moxham, 2008; Kerby et al., 2011; Moxham et al., 2015; Moxham et al., in press) that regional anatomy, an approach that has clinical relevance to trauma, surgery and radiology and that is best placed to allow professionalism and skills acquisition by allowing students to perform dissections, should NOT be an elective course that restricts student admission (unless the criteria for admission indicates a preference for the appropriate specialist career pathways). Consequently, elective courses in regional anatomy do not ameliorate the adverse effects of removing them from the standard (obligatory or core) courses and indeed we would argue strongly that to put regional anatomy into electives further downgrades the subject in the minds of educators and students as a whole since it would not be seen as being 'core.'

\section{CONCLUSIONS AND RECOMMENDATIONS}

There is surprising little evidence in the literature to evaluate the effects of introducing optional/elective courses in medical education and medical practice and, in particular, until core material is defined (and generally agreed) in the medical curriculum then optionality has conceptually no real foundation. Furthermore, it is worrying that the diversity of elective courses (including content, teaching methodologies, assessment, admissions, and outcomes) detracts from the important educational principles of CONSISTENCY, RELIABILITY, and TRANSPARENCY. Indeed, medical education worldwide is already 
fractured by a high degree of diversity such that there is difficulty in appreciating the standards set (and thus the quality of future medical practitioners) once they have completed their medical degree. Furthermore, in our increasingly consumerist societies, laypersons (patients and potential patients) are the consumers and they will increasingly expect appropriate standards to be achieved and consistency between institutions and medical curricula to be applied. It can be concluded overall that further independent research and analysis is required to assess the educational value of elective courses and optionality that does not rely upon student questionnaires that just investigate the levels of 'satisfaction' with their courses.

We recommend that for regional anatomy the course should remain 'core' and within the standard medical course but that more advanced regional anatomy courses might be introduced with benefit at late stages within the medical course, not just for revision and reinforcement but to help satisfy clear career aspirations. We further advocate that regional anatomy should persist with the use of cadavers (although preferably with student dissection). Where electives or student selective components are to be formulated for anatomy, these should not deal specifically with the scientific knowledge of the discipline but should provide added benefits for skills and/or an understanding of the culture and history of anatomy. For example, advanced dissection with a surgical approach, the history of anatomy, art and anatomy, and life drawing (related to surface anatomy) can all be optional courses. Such courses would not detract from the difficulties of understanding core anatomical information nor would they disadvantage students (particularly in the early years of the medical course) with respect to their eventual career pathways.

\section{ABOUT THE AUTHORS}

Both authors are professors of anatomy and are, or have been, course directors/heads of an academic department. Professor Moxham is emeritus and has taught on elective courses (but not elective gross anatomical courses), while Professor Pais presently teaches on both standard (obligatory) anatomy courses and on elective (optional) anatomy courses. Both are members of the Trans-European Pedagogic Anatomical Research Group (TEPARG) and have published extensively on matters relating to medical education.

\section{REFERENCES}

Abdul-Ghani AN. 2006. Anatomy teaching. Surgeon 4:60.

Agarwal A, Wong S, Sarfaty S, Devaiah A, Hirsch AE. 2015. Elective courses for medical students during the preclinical curriculum: A systematic review and evaluation. Med Edu Online 20:26615. http://dx.doi.org/10.3402/meo.v20.26615

Ahmed K, Rowland S, Patel VM, Ashrafian H, Davies DC, Darzi A, Athanasiou T, Paraskeva PA. 2011. Specialist anatomy: Is the structure of teaching adequate? Surgeon 9:312-317.
Amataguirre E. 1963. The lack of cadavers as a problem in investigation and teaching of anatomy. Recognition and plan for solution. Arch Esp Morfol 17:273-284.

Ampil DG. 1949. The teaching of anatomy. Acta Med Philipp 5:67-75. Andrea VD, Malinovsky L, Biancari F. 1996. Teaching of anatomy: A job for a biologist or a surgeon? Eur J Surg 162:350.

Anson BJ. 1956. The history of anatomy in medical education. Q Bull Northwest Univ Med Sch 30:80-94.

Anson BJ. 1961. Outline for a course in the history of anatomy. I. Outline of topics with commentary. Q Bull Northwest Univ Med Sch 35:269-278.

Anson BJ, Davenport HA. 1954. Students appraisal of the teaching of gross anatomy. Q Bull Northwest Univ Med Sch 28:193-197.

Banerjee A, Bancil AS. 2011. Teaching of anatomy: Is there more to consider? Clin Anat 24:510.

Barberini F, Brunone F. 2008. A "conservative" method of thoracic wall dissection: A proposal for teaching human anatomy. Ital ] Anat Embryol 113:187-195.

Bay $\mathrm{BH}$, Ling EA. 2007. Teaching of anatomy in the new millennium. Singapore Med J 48:182-183.

Berry RJ. 1921. The teaching and study of human anatomy. Br Med J $1: 75-77$.

Bhadkamkar AR, Bhatt VP. 1959. The availability of cadavers in the teaching of anatomy. Indian J Med Sci 13:518-521.

Bird MM. 1979. Scientists teaching gross anatomy. Med Educ 13: 237-238.

Braun RA. 2014. Are we teaching enough anatomy? Clin Anat 27: 146.

Buckenham T. 2013. Undergraduate anatomy teaching: Whose responsibility? J Med Imaging Radiat Oncol 57:261-262.

Burgess AW, Ramsey-Stewart G, May J, Mellis C. 2012. Team-based learning methods in teaching topographical anatomy by dissection. ANZ J Surg 82:457-460.

Cahill DR, Leonard RJ, Marks SC Jr. 2000. A comment on recent teaching of human anatomy in the United States. Surg Radiol Anat 22:69-71.

Chew FS, Relyea-Chew A, Ochoa ER Jr. 2006. Postmortem computed tomography of cadavers embalmed for use in teaching gross anatomy. J Comput Assist Tomogr 30:949-954.

Collett TD, Kirvell D, Nakorn A, McLachlan JC. 2009. The role of living models in the teaching of surface anatomy: some experiences from a UK Medical School. Med Teach 31:e90-e96.

Collins JP. 2008. Modern approaches to teaching and learning anatomy. Br Med J 337:a1310.

Coupland RE, Tresidder GC, Green NA. 1976. The teaching of anatomy. Report of a conference held at the Royal College of Surgeons of England on $26^{\text {th }}$ May 1976. Ann R Coll Surg Engl 58: 434-439.

de Barros N, Rodrigues CJ, Rodrigues AJ, Jr de Negri Germano MA, Cerri GG. 2001. The value of teaching sectional anatomy to improve CT scan interpretation. Clin Anat 14:36-41.

Dettmer S, Tschernig T, Galanski M, Pabst R, Rieck B. 2010. Teaching surgery, radiology and anatomy together: the mix enhances motivation and comprehension. Surg Radiol Anat 32:791-795.

Dewhurst K. 1958. Locke and Sydenham on the teaching of anatomy. Med Hist 2:1-12.

Dinsmore CE, Daugherty S, Zeitz HJ. 1999. Teaching and learning gross anatomy: Dissection, prosection, or "both of the above?" Clin Anat 12:110-114.

Drake RL, Lowrie DJ, Prewitt CM. 2002. Survey of gross anatomy, microscopic anatomy, neuroscience, and embryology courses in medical school curricula in the United States. Anat Record 269: 118-122.

Drake RL, McBride JM, Lachman N, Pawlina W. 2009. Medical education in the anatomical sciences: The winds of change continue to blow. Anat Sci Educ 2:253-259.

Drake RL, McBride JM, Pawlina W. 2014. An update on the status of anatomical sciences education in United States Medical Schools. Anat Sci Educ 7:321-325.

Dwight T. 1896. The Teaching of Anatomy. Science 4:142-143. 
Esperanca-Pina JA. 1976a. Ensino e investigação da Anatomia Humana I. Evolução do ensino de Anatomia Humana. O Médico 27:401.

Esperanca-Pina JA. 1976b. Ensino e investigação da Anatomia Humana II. Perspectivas do ensino e da investigação da Anatomia Humana. O Médico 27:463.

Esperanca-Pina JA, Bensabat-Rendas A, Correia M, Morais-Sarmento C, Eiro G, Leitao-de-Freitas A, Futre G, Bernardes AJ, Rodrigues J. 1980. O ensino da disciplina de Anatomia I na Faculdade de Ciências Médicas de Lisboa. Experiência do ano lectivo 1978/79. Acta Med Port 2:295-301.

Fitzpatrick CM, Kolesari GL, Brasel KJ. 2001. Teaching anatomy with surgeons' tools: Use of the laparoscope in clinical anatomy. Clin Anat 14:349-353.

Fitzgerald JE, White MJ, Tang SW, Maxwell-Armstrong CA, James DK. 2008. Are we teaching sufficient anatomy at medical school? The opinions of newly qualified doctors. Clin Anat 21:718-724.

Forrester D. 1971. Teaching anatomy through radiology. A new challenge requiring new techniques. Radiology 100:561-565.

Friel DJ. 1963. Teaching and learning anatomy. Radiography 29: 284-289.

General Medical Council. (1993) Tomorrow's Doctors: Recommendations on Undergraduate Medical Education. 1st Ed. London, UK: General Medical Council. p 28.

General Medical Council. (2009) Tomorrow's Doctors: Outcomes and Standards, for Undergraduate Medical Education. Regulating Doctors, Ensuring Good Medical Practice. 3rd Ed. London, UK: General Medical Council. p 104.

Griffioen FM, Drukker J, Hoogland PV, Godschalk M. 1999. General plan anatomy objectives of the teaching of anatomy/embryology in medical curricula in the Netherlands. Eur J Morphol 37:228325.

Gunderman RB, Wilson PK. 2005. Viewpoint: exploring the human interior: the roles of cadaver dissection and radiologic imaging in teaching anatomy. Acad Med 80:745-749.

Hamel EG Jr. 1975. Editorial: The gift of life. Anatomical donations and the teaching of anatomy. Ala J Med Sci 12:188-189.

Hamilton WJ. 1947. The teaching of anatomy. Surgo Glasg Univ Med J 13:61-63.

Hattie J. 2009. Visible Learning.Oxford: Routledge.

Hill AM, Shalhoub J. 2011. Teaching of anatomy through cadaveric dissection: Are we really satisfied? $\mathrm{Br}$ J Hosp Med (London) 72: 535.

Jack A, Burbridge B. 2012. The utilisation of radiology for the teaching of anatomy in Canadian medical schools. Can Assoc Radiol J 63:160-164.

Jamshidi R, Harris H, Campbell AR. 2008. The value of teaching anatomy to medical students. Bull Am Coll Surg 93:36.

Johnson JH. 2002. Importance of dissection in learning anatomy: Personal dissection versus peer teaching. Clin Anat 15:38-44.

Jones DG. 1997. Anatomy departments and anatomy education: Reflections and myths. Clin Anat 10:34-40.

Kerby J, Shukur ZN, Shalhoub J. 2011. The relationships between learning outcomes and methods of teaching anatomy as perceived by medical students. Clin Anat 24:489-497.

Khan AM. 1947. Undergraduate teaching in anatomy. Ind Med Gaz 82:145-156.

Kilroy D, Driscoll P. 2006. Determination of required anatomical knowledge for clinical practice in emergency medicine: National curriculum planning using a modified Delphi technique. Emerg Med J 23:693-696.

Korf HW, Wicht H, Snipes RL, Timmermans JP, Paulsen F, Rune G, Baumgart-Vogt E. 2008. The dissection course-necessary and indispensable for teaching anatomy to medical students. Ann Anat 190:16-22.

Krych AJ, March CN, Bryan RE, Peake BJ, Pawlina W, Carmichael SW. 2005. Reciprocal peer teaching: Students teaching students in the gross anatomy laboratory. Clin Anat 18:296-301.

Leonard RJ, Acland RD, Agur A, et al. 1996. A clinical anatomy curriculum for the medical student of the 21st century: gross anatomy. Clin Anat 9:71-99.
Leonard RJ, Hoos PC, Agud R, et al. 2000. A clinical anatomy curriculum for the medical student of the 21st Century: Developmental anatomy. Clin Anat 13:17-35.

Linton 0. 2006. Current survey of the role of radiology in teaching anatomy to medical students. Acad Radiol 13:1444.

Lockwood CB. 1888. An address on the teaching of anatomy. Br Med J 2:1372-1373.

McLachlan JC, Patten D. 2006. Anatomy teaching: Ghosts of the past, present and future. Med Educ 40:243-253.

McLachlan JC, Bligh J, Bradley P, Searle J. 2004. Teaching anatomy without cadavers. Med Educ 38:418-424.

McHanwell S, Davies DC, Morris J, Parkin I, Whiten S, Atkinson M, Dyball R, Ockleford C, Standring S, Wilton J. 2007. A core syllabus in anatomy for medical students-Adding common sense to need to know. Eur J Anat 11:3-18.

McMurray TP. 1949. Teaching of anatomy to the medical student. $\mathrm{Br}$ Med J 2:510-512.

Memon I. 2009. Future of anatomy teaching in new medical curriculum. J Pak Med Assoc 59:125.

Mitchell BS, McCrorie P, Sedgwick P. 2004. Student attitudes towards anatomy teaching and learning in a multiprofessional context. Med Educ 38:737-748.

Mitchell R, Batty L. 2009. Undergraduate perspectives on the teaching and learning of anatomy. ANZ J Surg 79:118-121.

Morley L. 2003. Quality and Power in Higher Education. London, Maidenhead, Berkshire: Open University Press and Society for Research into Higher Education.

Mottershead S. 1980. The teaching of anatomy and its influence on the art and practice of surgery. Br Med J 280:1306-1309.

Moxham BJ, Moxham SA. 2007. The relationships between attitudes, course aims and teaching methods for the teaching of gross anatomy in the medical curriculum. Eur ] Anat 11:19-30.

Moxham BJ, Plaisant O. 2007. Perception of medical students towards the clinical relevance of anatomy. Clin Anat 20:560-564.

Moxham BJ, Shaw H, Crowson R, Plaisant O. 2011. The future of clinical anatomy. Eur J Anat 15:5-22.

Moxham BJ, Plaisant O, Smith CF, Pawlina W, McHanwell S. 2014. An approach toward the development of core syllabuses for the anatomical sciences. Anat Sci Educ 7:302-311.

Moxham BJ, McHanwell S, Plaisant O, Pais D. 2015. A core syllabus for the teaching of neuroanatomy to medical students. Clin Anat 28:706-716.

Moxham BJ, Emmanouil-Nikoloussi E, Standley H, Brenner E, Plaisant O, Brichova H, Pais D, Stabile I, Borg J, Chirculescu A. 2016. The attitudes of medical students in Europe toward the clinical importance of embryology. Clin Anat 29:144-150.

Moxham BJ, Hennon H, Lignier B, Plaisant O. (2016). An assessment of the anatomical knowledge of laypersons and their attitudes toward the clinical importance of gross anatomy in medicine. Annals Anat. http://dx.doi.org/10.1016/j.anat.2016.06.001.

Mukhtar Y, Mukhtar S, Chadwick SJ. 2009. Lost at sea: Anatomy teaching at undergraduate and postgraduate levels. Med Educ 43:1078-1079.

Murphy MA, Handa A. 2004. Re: Anatomy: A must for teaching the next generation. J Older Surg J R Coll Surg Edinb Irel 2:2:79-90. Surgeon 2:303-304, Author reply 304.

Naz S, Nazir G, Iram S, Mohammad M, Umair, Qari IH Mohammad S. 2011. Perceptions of cadaveric dissection in anatomy teaching. J Ayub Med Coll Abbottabad 23:145-148.

Nutt J, Mehdian R, Parkin I, Dent J, Kellett C. 2012. Cadaveric surgery: A novel approach to teaching clinical anatomy. Clin Teach 9:148-151.

Older J. 2004. Anatomy: a must for teaching the next generation. Surgeon 2:79-90.

Pais D. 1997. Anatomia: Relatório Pedagógico-O ensino da Anatomia por Estágios de Curta Duração Intensivos (ECDI). Lisboa: Universidade Nova de Lisboa.

Pais D, Moxham BJ. 2013. Should gross anatomy be taught systemically or regionally? Eur J Anat 17:43-47.

Patel KM, Moxham BJ. 2006. Attitudes of professional anatomists to curricular change. Clin Anat 19:132-141. 
Patel KM, Moxham BJ. 2008. The relationships between learning outcomes and methods of teaching anatomy as perceived by professional anatomists. Clin Anat 21:182-189.

Pereira TG, Rosado-Pinto P. 1995. Ensino por Problemas: Experiência de Cinco Anos num Disciplina Básica. Educação Médica 6:131-133.

Pinto-Machado J. 1991. O Ensino-Aprendizagem de Anatomia: Uma resposta a um dos Desafios Actuais. Educação Médica 2:2-12.

Pinto-Machado J. 1992. Para uma Reforma da Educação Médica. Educação Médica 3:56-61.

Pinto-Machado J. 1995. O Cadáver Humano e o Estudo da Anatomia (passado, Presente e Futuro). Educação Médica 6:134-149.

Pinto-Machado J. 1996. Curso de Medicina da Faculdade de Medicina do Porto: Disciplina de Anatomia Clínica. Educação Médica 7:2-12.

Plaisant O, Delmas V, Cabanis EA, Lassau JP. 2001. Enseignement de I'anatomie humaine dans une Faculté de médecine américaine. Presse Med 30:29-34.

Plaisant O, Cabanis EA, Delmas V. 2004. Going back to dissection in a medical curriculum: The paradigm of Necker-Enfants Malades. Surg Radiol Anat 26:504-511.

Purkayastha S, Paraskevas P, Darzi A. 2007. Make surgeons more active in teaching anatomy at all levels. Br Med J 334:110.

Ramsey S. 2005. Changing times, changing training: Anatomy teaching in basic surgical training. Clin Anat 18:467-468.

Regan de Bere S, Petersen A. 2006. Out of the dissecting room: News media portrayal of human anatomy teaching and research. Soc Sci Med 63:76-88.

Rizzolo LJ, Stewart WB. 2006. Should we continue teaching anatomy by dissection when...? Anat Rec B: New Anat 289:215-218.

Rosado-Pinto P. 1993. Aprendizagem por Análise e Resolução de Problemas: Fundamentos Pedagógicos e Estratégias de Formação. Educação Médica 4:10-17.

Rosado-Pinto P, Bensabat-Rendas A. 1994. Aprendizagem Autónoma (Self- Directed Learning): Relatório de um Atelier Pedagógico. Educação Médica 5:178-181.
Rulli F. 2004. Re: Anatomy: A must for teaching the next generation. J Older Surg J R Coll Surg Edinb Irel 2 2:79-90. Surgeon 2(5): 303; author reply 303.

Schweisthal MR, White RP. 1970. Use of fresh specimens in teaching head and neck anatomy. J Oral Surg 28:747-752.

Scott JL, Moxham BJ, Rutherford SM. 2014. Building an open academic environment-A new approach to empowering students in their learning of anatomy through 'Shadow Modules'. J Anat 224: 286-295.

Seyfer AE, Welling D, Fox JP. 2007. The value of surgeons teaching anatomy to first-year medical students. Bull Am Coll Surg 92:8-14.

Smith CF, Finn GM, Stewart J, Lee TC, Gillingwater TH, McHanwell S. 2016. A new core gross anatomy syllabus for medicine. Anat Sci Educ 9:209-210.

Smith JA. 2005. Can anatomy teaching make a come back? ANZ J Surg 75:93.

Stansby G. 2004. Teaching anatomy without cadavers. Med Educ 38:911; author reply 912-913.

Swamy M, Venkatachalam S, McLachlan J. 2014. A Delphi consensus study to identify current clinically most valuable orthopaedic anatomy components for teaching medical students. BMC Med Educ 14:230.

Tubbs RS, Sorenson EP, Sharma A, Benninger B, Norton N, Loukas M, Moxham BJ. 2014. The development of a core syllabus for the teaching of head and neck anatomy to medical students. Clin Anat 27:321-330.

Von Bonin G. 1947. Some thoughts on teaching anatomy. J Assoc Am Med Coll 22:38-42.

Walsh JJ. 1904. The Popes and the history of anatomy. Med Library Hist ] 2:10-28.

Wong WC, Tay SS. 2005. The teaching of anatomy: the first hundred years (1905-2005). Ann Acad Med Singapore 34:72C-78C.

$\mathrm{Xu}$ B. 2008. Traditional anatomy teaching and problem-based learning: is there a middle way? ANZ J Surg 78:6. 